\title{
Cerebellar degeneration in primary Sjögren syndrome: a case report
}

\author{
Seow Lin Chuah ${ }^{1}$, Ahmad Tirmizi Jobli²*0, Sharifah Aishah Wan ${ }^{1}$ and Cheng Lay Teh ${ }^{1}$
}

\begin{abstract}
Background: Cerebellar degeneration is a rare and severe presentation of primary Sjögren syndrome. There are few case reports of cerebellar degeneration associated with different autoimmune diseases, especially with systemic lupus erythematosus and neuro-Behcet's disease. There are only six patients reported worldwide to be affected by cerebellar atrophy associated with primary Sjögren syndrome. In this report, we describe a patient with primary Sjögren syndrome who presented with ataxia due to cerebellar degeneration.

Case presentation: We report the case of a 37-year-old Chinese woman with primary Sjögren syndrome who presented with ataxia over 3 months associated with tremor of the limbs. Magnetic resonance imaging of the brain revealed bilateral cerebellar atrophy. Based on the presence of cerebellar signs with magnetic resonance imaging brain findings, she was diagnosed as cerebellar degeneration secondary to primary Sjögren syndrome. She was treated with methylprednisolone, hydroxychloroquine, and two cycles of monthly intravenous cyclophosphamide. Subsequently, she refused further treatment, and her neurological symptoms remained the same upon the last clinic review. Primary cerebellar degeneration is rarely associated with primary Sjögren syndrome. The pathogenesis of the neurological manifestations in primary Sjögren syndrome is unclear. Treatment involves corticosteroids and immunosuppressive agents with no consensus of a specific therapy for the management of primary Sjögren syndrome with central nervous system involvement.
\end{abstract}

Conclusions: Cerebellar degeneration is a rare presentation of primary Sjögren syndrome. Early diagnosis and treatment of this condition is needed to ensure a good outcome.

Keywords: Sjögren syndrome, Ataxia, Cerebellar atrophy, Cyclophosphamide

\section{Background}

Primary Sjögren syndrome (PSS) is an autoimmune connective tissue disease, characterized by mononuclear infiltration and destruction of salivary and lacrimal glands leading to xerostomia and xerophthalmia. It predominantly affects female patients between 40 and 50 years of age [1].

SS may occur as primary or secondary to another connective tissue disease (mainly systemic lupus

\footnotetext{
*Correspondence: jatirmizi@unimas.my

${ }^{2}$ Radiology Department, Faculty of Medicine and Health Sciences, University Malaysia Sarawak, Kota Samarahan, Malaysia

Full list of author information is available at the end of the article
}

erythematosus, rheumatoid arthritis, or scleroderma). Approximately $35 \%$ of patients with primary Sjögren syndrome (PSS) suffer from systemic manifestations [2]. Neurological disorders are one of the extraglandular manifestations of the disease. In $25-60 \%$ of cases, the neurological symptoms preceded the diagnosis of PSS by 2 years. In the remaining patients, neurological disorders appeared $6-8$ years after diagnosis [3].

The prevalence of neurological manifestations in PSS varies widely from $10 \%$ to $60 \%$ [4-6]. The most common neurological complication of PSS is peripheral neuropathy, particularly sensory polyneuropathy [7]. Central nervous system (CNS) involvement is much less common $(2-25 \%)[8,9]$. Although ataxia due to PSS has also been

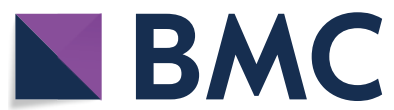

(c) The Author(s) 2021. Open Access This article is licensed under a Creative Commons Attribution 4.0 International License, which permits use, sharing, adaptation, distribution and reproduction in any medium or format, as long as you give appropriate credit to the original author(s) and the source, provide a link to the Creative Commons licence, and indicate if changes were made. The images or other third party material in this article are included in the article's Creative Commons licence, unless indicated otherwise in a credit line to the material. If material is not included in the article's Creative Commons licence and your intended use is not permitted by statutory regulation or exceeds the permitted use, you will need to obtain permission directly from the copyright holder. To view a copy of this licence, visit http://creativecommons.org/licenses/by/4.0/. The Creative Commons Public Domain Dedication waiver (http://creativeco mmons.org/publicdomain/zero/1.0/) applies to the data made available in this article, unless otherwise stated in a credit line to the data. 
described, marked cerebellar atrophy associated with PSS has rarely been reported $[10,11]$. There are few reports of cerebellar degeneration associated with different autoimmune diseases, especially with SLE $[12,13]$ and neuroBehcet's disease $[14,15]$. In this case report, we describe a patient with PSS who presented with ataxia due to cerebellar degeneration.

This case highlights the challenges in the evaluation of a patient who presents with cerebellar signs. There is a wide range of potential causes that need to be considered and excluded. We also performed a literature review of previously published cases.

\section{Case presentation}

A 37-year-old Chinese female with a history of primary Sjögren syndrome presented with progressive unsteady gait for 3 months. She first presented with inflammatory arthritis involving bilateral shoulders, wrists, hands, knees, and feet in 2014. She also had sicca syndrome, and she tested positive for Schirmer's test in both eyes. Her anti-SSA was positive. Laboratory tests were positive for speckled-type antinuclear antibodies and rheumatoid factor. Anti-double-stranded deoxyribonucleic acid (anti dsDNA) antibody test was negative. Assay for antiphospholipid antibodies (anticardiolipin and anti-B2 glycoprotein), SS-B/anti-La, human immunodeficiency virus (HIV) antibody, hepatitis B surface antigen (Hbs antigen), and hepatitis $\mathrm{C}$ virus (HCV) antibody were all negative. She was diagnosed as PSS and treated with prednisolone, hydroxychloroquine, and methotrexate. One year later, she developed bilateral lower limb numbness and a nerve conduction study showed evidence of mononeuritis multiplex involving bilateral tibial and peroneal nerves. She was treated with intravenous methylprednisolone leading to full neurological recovery later.

In August 2016, she presented with bruises, thrombocytopenia (platelets $5 \times 10^{3} / \mu \mathrm{L}$ ) and leukopenia (total white cells (TWC): $3.3 \times 10^{3} / \mu \mathrm{L}$ ). She underwent further workup, and bone marrow aspiration and trephine (BMAT) showed increased megakaryopoiesis, which was suggestive of peripheral destruction of platelet. B-lymphoproliferative studies showed no evidence of clonal B-lymphoproliferative disorder. Computed tomography (CT) of the neck, thorax, abdomen, and pelvis revealed multiple prominent intraparotid, cervical, left supraclavicular, and bilateral axillary lymph nodes; posterior nasopharynx diffuse bulkiness was likely due to lymphoid tissue. Fine needle aspiration cytology (FNAC) of posterior nasal space demonstrated scattered lymphoid cells likely due to florid reactive lymphoid proliferation. She was treated with intravenous immunoglobulin (IVIG) $1 \mathrm{mg} / \mathrm{kg} /$ day and followed by prednisolone $70 \mathrm{mg}$ with gradual tapering dose. Her blood counts normalized subsequently. In 2017, she was treated for herpes zoster infection.

In January 2018, she had palpable cervical lymph nodes. CT scan reported multiple prominent lymph nodes in the neck and diffuse enlargement of the parotid glands. The large right-sided intraparotid mass was markedly reduced. The axillary lymph nodes noted previously had also reduced. However, interval development of multiple pulmonary nodules with areas of consolidation were seen. There were stable cystic changes in the lungs. Biopsy of the posterior nasal space showed atypical lymphoid infiltrate. Flow cytometry of the posterior nasal space reported intermediate-size, kappa-restricted B-cells along with increased plasma cells, suggestive of marginal zone lymphoma. PET scan revealed fluorodeoxyglucose (FDG)-avid bilateral cervical, and right intraparotid nodes were suspicious for disease. Bilateral multiple minimal to intensely FDG-avid pulmonary nodules of varying sizes were seen. Subsequently, she refused further interventions and was discharged with hydroxychloroquine $200 \mathrm{mg}$, prednisolone $7.5 \mathrm{mg}$, and calcium carbonate $1 \mathrm{~g}$ daily.

There was history of nonadherence to medical therapy since 2014. She was not under rheumatology follow-up since March 2018. She only took $5 \mathrm{mg}$ of prednisolone, $500 \mathrm{mg}$ of calcium carbonate, and thyroxine $100 \mu \mathrm{g}$ daily from her general practitioner after she was noted to have hypothyroidism.

She presented to us in 2019 with 3 months history of unsteady gait and tremors over all four limbs. There was no family history of gait disturbance or familial history of neurological disorders. The patient had no exposure to toxins such as alcohol. She denied smoking and recreational drug usage. She was married with no children. She lost her job as a clerk since she acquired unsteady gait. There was no known food intolerance, medication allergy, or significant past surgical history.

On examination, the patient was afebrile and normotensive with a pulse rate of 80 beats per minute. Respiratory, cardiovascular, and abdominal examinations were normal. Her neurological examination revealed ataxia. She was unable to walk without assistance. She also had dysmetria, dysarthria, and intention tremor of the four limbs, especially her hands. Other motor and sensory examinations were normal. Her deep tendon reflexes were normoactive, and her plantar responses were flexor bilaterally. She had horizontal nystagmus and titubation. Examination of the cranial nerves did not reveal any abnormalities. There was Jaccoud deformity of both hands with limited range of movement of the right wrist. 
She did not have active synovitis. Left parotid swelling was present. There was no lymphadenopathy.

\section{Investigations}

Laboratory investigations reveal hemoglobin of $11.8 \mathrm{~g} /$ $\mathrm{dL}$, white blood cells of $5.08 \times 10^{3} / \mu \mathrm{L}$, and platelet counts of $285 \times 10^{3} / \mu \mathrm{L}$. Her renal profile revealed creatinine level of $60 \mathrm{mmol} / \mathrm{L}$ with no electrolyte imbalance. Liver function test showed slightly low albumin level at $33 \mathrm{~g} / \mathrm{L}$ with normal liver enzymes. Urinalysis did not show significant abnormality. Thyroid function tests were normal with T4 of $13.3 \mu \mathrm{g} / \mathrm{dL}$ and TSH of $4.09 \mathrm{mU} / \mathrm{L}$. Serum glucose level was $5.1 \mathrm{mmol} / \mathrm{L}$. Paraneoplastic markers such as anti-Yo, Ri, Ma, Hu, CV2, and amphiphysin were all negative. Magnetic resonance imaging (MRI) of brain showed cerebellar atrophy (Fig. 1). CT neck/thorax showed bilateral parotid and submandibular microcytic appearance with cystic lung and airspace opacities suggestive of lymphocytic interstitial pneumonia. Fine needle aspiration cytology (FNAC) of the left parotid gland was done and revealed reactive lymphoid hyperplasia.

With her background of poorly controlled PSS and clinical features of cerebellar signs consistent with the MRI findings, she was diagnosed with cerebellar degeneration secondary to PSS. She was treated with intravenous methylprednisolone $500 \mathrm{mg}$ daily for 3 days and then maintenance therapy with oral prednisolone $30 \mathrm{mg}$ daily. One gram of intravenous cyclophosphamide was also administered, and she was planned for further monthly cycles of cyclophosphamide. She was started on $200 \mathrm{mg}$ of hydroxychloroquine. Tenofovir was given in view of her positive hepatitis B core antibody. She was seen by hematology team, and the team commented that the initial suspicious of marginal zone lymphoma in January 2018 was probably erroneous as the lesions did not progress. She received two cycles of monthly intravenous cyclophosphamide. Subsequently, she refused further treatment in our center and opted for a second opinion. The patient was lost to follow-up after that. Upon last follow-up, her neurological symptoms remained the same.

\section{Discussion}

We report the case of a 37-year-old woman with primary Sjögren syndrome who presented with ataxia over 3 months associated with tremor of the limbs. Based on the presence of cerebellar signs with MRI brain findings, she was diagnosed with cerebellar degeneration secondary to PSS. Primary cerebellar degeneration is rarely associated with PSS. We evaluated possible causes of primary cerebellar degeneration in our patient, including alcohol, drug abuse, paraneoplastic manifestations, autoimmune disorders, and a rare manifestation of HIV infection [16]. Diagnosis by exclusion ultimately led to the conclusion that her cerebellar degeneration was due to poorly controlled PSS. Her disease was not well controlled since onset in 2014, which involved the joints, hematological, and neurological system.

Our patient had both peripheral and central nervous system involvement as evidenced by her previous history of mononeuritis multiplex and the current onset of cerebellar ataxia due to cerebellar atrophy. In contrast to the uniform features of the peripheral nervous system complications of PSS, CNS abnormalities are associated with a much wider spectrum of manifestations. In the largest cohort of 431 PSS patients published in 2010, the most frequent picture of CNS involvement was a recurrent
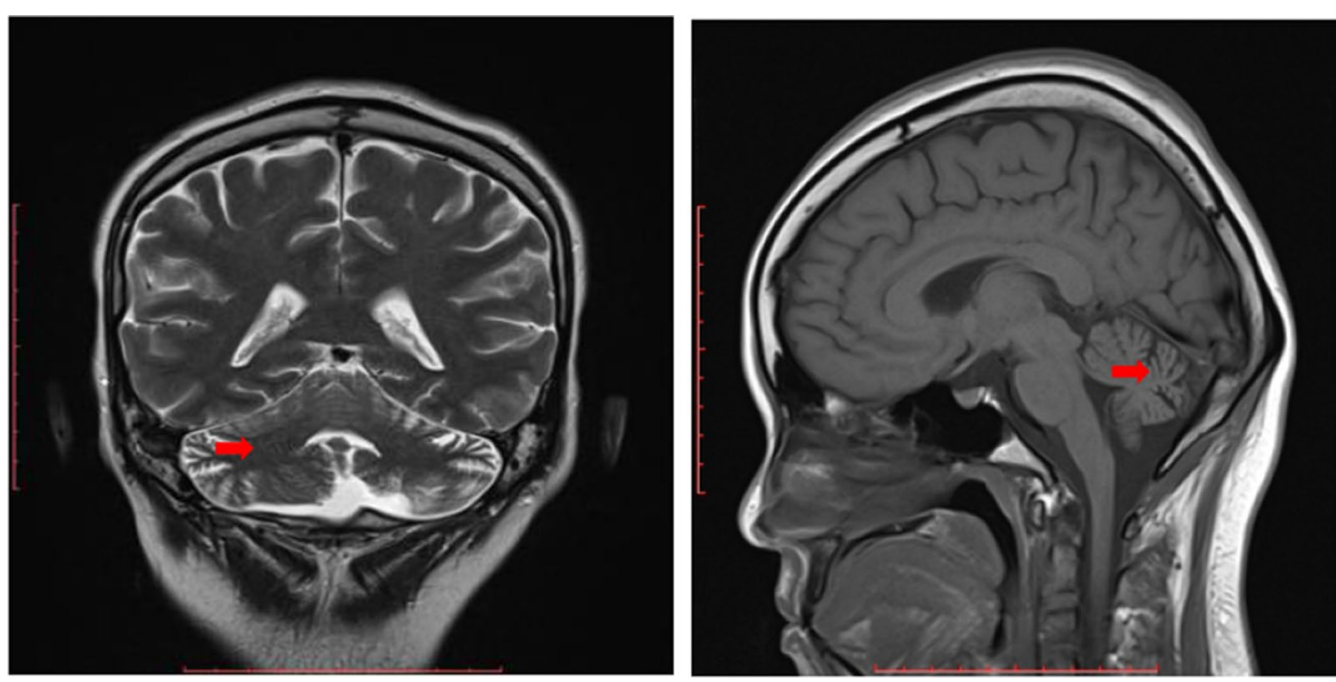

Fig. 1 Coronal T2WI (left) and sagittal T1WI (right) showing atrophy of the superior and inferior cerebellar vermis (arrow) 
subacute encephalopathy characterized by memory loss, cognitive dysfunction, visual disturbances, and dizziness [10]. The first description of cerebellar syndrome in association with PSS was defined by Attwood and Poser in 1961 [17]. Primary cerebellar degeneration is rarely associated with PSS. To our knowledge, there are only six case reports (Table 1 ) of cerebellar atrophy associated with PSS [11, 18-22].

The first case of cerebellar ataxia with cerebellar atrophy was reported by Terao et al. in 1994 [18]. The patient was a 61-year-old gentleman who presented with progressive onset of ataxia and vertigo. His neurological symptoms improved with steroids alone. There was another study by Heidary et al. in 2018 in which the patient's cerebellar ataxia improved with steroids and cyclophosphamide [19]. In contrast to these two studies, our patient did not have similar neurological improvement despite being given a high dose of steroid and cyclophosphamide. The suboptimal control of her disease since 2014 and delay in seeking medical treatment probably contributed to her poor outcome. Her cerebellar atrophy is most likely irreversible. In the other four case reports, there was no significant neurological improvement by medical treatment [11, 20-22]. To date, there is no consensus of a specific therapy for the management of Sjögren's syndrome with CNS involvement.

The pathophysiology of cerebellar atrophy in SS has yet to be elucidated. Some studies have postulated that antibodies and ischemia may play a significant role, resulting in microinfarcts or macroinfarcts
$[4,23]$. In addition to cerebellar atrophy, Terao et al. [18] and Farhat et al. [21] reported additional signs of CNS inflammation, such as gadolinium enhancement or cerebellar white-matter fluid attenuated inversion recovery (FLAIR) hyperintensities, which were absent in our patient. The absence of hyperintense lesions on MRI suggests that vasculitis or demyelination is unlikely in our case. Owada et al. [11] and Terao et al. [18] reported presence of an autoantibody reactive to Purkinje cells in the CSF. We did not test for the presence of common antineuronal antibodies as the test was unavailable. However, most published cases of SS-related cerebellar degeneration reported negative antineuronal antibodies screen [20,21]. The course of the disease of neuro-Sjögren can be multiple sclerosislike with relapsing-remitting modality or progressive. In Massara's paper, it was proven that CNS involvement may even precede clinical diagnosis of SS by many years, with patients misdiagnosed as multiple sclerosis fulfilling the diagnosis criteria [10].

The risk of B-cell lymphoma in PSS patients is 15 to 20 times higher than in the general population (lifetime risk, 5-10\%), a finding that has been attributed to the chronic B-cell activation in this PSS. These lymphomas are mostly B-cell non-Hodgkin's lymphomas with a predominance of the low-grade, marginal-zone histological type. Lymphomas often develop in organs in which PSS is active, such as the salivary glands and thus are primarily mucosa-associated lymphoid tissue (MALT) lymphomas $[24,25]$. Our patient is at high risk of having lymphoma

Table 1 Previous reports of cerebellar degeneration secondary to PSS

\begin{tabular}{|c|c|c|c|c|c|c|c|}
\hline & Age & Sex & Neurologic deficits & MRI brain findings & Autoantibody & Treatment received & $\begin{array}{l}\text { Treatment } \\
\text { effect }\end{array}$ \\
\hline Terao et al. 1994 & 61 & M & Ataxia, dysarthria, vertigo & $\begin{array}{l}\text { Cerebellar and frontal } \\
\text { lobe atrophy, multiple } \\
\text { high-signal-intensity } \\
\text { lesions }\end{array}$ & Antineuronal Ab (+) & Steroid & + \\
\hline Owada et al. 2002 & 55 & $\mathrm{~F}$ & $\begin{array}{l}\text { Motor weakness, ataxia, } \\
\text { sensory disturbance, } \\
\text { depression, apathy }\end{array}$ & $\begin{array}{l}\text { Cerebellar and cerebral } \\
\text { cortex atrophy }\end{array}$ & Antineuronal Ab (+) & Steroid & - \\
\hline Kim et al. 2012 & 46 & F & $\begin{array}{l}\text { Gait and limb ataxia, } \\
\text { depression, delusion }\end{array}$ & $\begin{array}{l}\text { Cerebellar atrophy with } \\
\text { an enlarged fourth ventri- } \\
\text { cle and cisterna magna }\end{array}$ & Paraneoplastic Ab (-) & Steroid & - \\
\hline Farhat et al. 2016 & 30 & F & $\begin{array}{l}\text { Cerebellar ataxia worsen- } \\
\text { ing over } 4 \text { years associ- } \\
\text { ated with tremor of the } \\
\text { limbs and the head }\end{array}$ & $\begin{array}{l}\text { Bilateral hyperintensi- } \\
\text { ties affecting periven- } \\
\text { tricular white matter, } \\
\text { with marked cerebellar } \\
\text { atrophy }\end{array}$ & Paraneoplastic Ab (-) & $\begin{array}{l}\text { Steroid and cyclophos- } \\
\text { phamide }\end{array}$ & - \\
\hline Maciel et al. 2017 & 36 & F & Ataxia, dysarthria & Cerebellar atrophy & Not done & $\begin{array}{l}\text { Steroid and cyclophos- } \\
\text { phamide }\end{array}$ & - \\
\hline Heidary et al. 2018 & 22 & $\mathrm{~F}$ & $\begin{array}{l}\text { Ataxia with tremor of four } \\
\text { limbs }\end{array}$ & Cerebellar atrophy & Not done & $\begin{array}{l}\text { Steroid and cyclophos- } \\
\text { phamide }\end{array}$ & + \\
\hline
\end{tabular}


based on positive rheumatoid factor, parotid gland enlargement, and chronic uncontrolled disease. Close monitoring of her risk of lymphoma is warranted. The initial suspicion of marginal lymphoma in January 2018 was probably erroneous as the lesions did not progress.

\section{Conclusion}

Our patient had severe cerebellar dysfunction that did not respond to medical treatment. Early diagnosis and aggressive treatment of cerebellar degeneration in PSS is essential to ensure good outcome. Further consensus on the treatment is needed.

\section{Abbreviations \\ PSS: Primary Sjögren syndrome; SLE: Systemic lupus erythematosus; CNS: Central nervous system; MRI: Magnetic resonance imaging; CT: Computed tomography; SS: Sjögren syndrome; BMAT: Bone marrow aspiration trephine; FNAC: Fine needle aspiration cytology; PET scan: Polyethylene terephthalate scan; CSF: Cerebral spinal fluid; MS: Multiple sclerosis.}

\section{Acknowledgements}

The authors would like to thank the Director-General of the Ministry of Health, Malaysia for permission to publish this article.

\section{Authors' contributions}

SL wrote the manuscript with the help of Jobli. Study concept and design: $C L, S A$. Acquisition of data: SL, Jobli. All authors read and approved the final manuscript.

\section{Funding}

Open Access funding provided by Universiti Malaysia Sarawak. The authors declare no external funding for this publication.

\section{Availability of data and materials}

The clinical data and images in this article are available from the authors upon reasonable request.

\section{Declarations}

\section{Ethics approval and consent to participate}

This case report was approved by the Director-General of the Ministry of Health, Malaysia.

\section{Consent for publication}

Written informed consent was obtained from the patient for publication of this case report and any accompanying images. A copy of the written consent is available for review by the Editor-in-Chief of this journal.

\section{Competing interests}

The authors declare that they have no competing interests.

\section{Author details}

${ }^{1}$ Rheumatology Unit, Medical Department, Sarawak General Hospital, Kuching, Malaysia. ${ }^{2}$ Radiology Department, Faculty of Medicine and Health Sciences, University Malaysia Sarawak, Kota Samarahan, Malaysia.

Received: 1 October 2019 Accepted: 9 September 2021

Published online: 19 October 2021

\section{References}

1. Kassan SS, Moutsopoulos HM. Clinical manifestations and early diagnosis of Sjögren syndrome. Arch Intern Med. 2004;164:1275-84.
2. Skopouli FN, Dafni U, Loannidis JP, Moutsopoulos HM. Clinical evolution, and morbidity and mortality of primary Sjögren's syndrome. Semin Arthritis Rheum. 2000;29(5):296-304

3. Fauchais AL, Magy L, Vidal E. Central and peripheral neurological complications of primary Sjögren's syndrome. Presse Med. 2012:41:485-93.

4. Alexander E. Central nervous system disease in Sjögren's syndrome. New insights into immunopathogenesis. Rheum Dis Clin N Am. 1992;18:637-72.

5. Mauch E, Völk C, Kratzsch G, Krapf H, Kornhuber HH, Laufen H, et al. Neurological and neuropsychiatric dysfunction in primary Sjögren's syndrome. Acta Neurol Scand. 1994;89:31-5.

6. Delalande S, de Seze J, Fauchais AL, Hachulla E, Stojkovic T, Ferriby D, et al. Neurologic manifestations in primary Sjögren syndrome: a study of 82 patients. Medicine. 2004;83:280-91.

7. Chai J, Logigian EL. Neurological manifestations of primary Sjögren's syndrome. Curr Opin Neurol. 2010;23:509-13.

8. Moutsopoulos HN, Sarmas JH, Talal N. Is central nervous system involvement a systemic manifestation of primary Sjögren's syndrome? Rheum Dis Clin N Am. 1993;19:909-12.

9. Andonopoulos AP, Lagos G, Drosos AA, Moutsopoulos HM. The spectrum of neurological involvement in Sjögren's syndrome. Br J Rheumatol. 1990;29:21-3.

10. Massara A, Bonazza S, Castellino G, Caniatti L, Trotta F, Borrelli M, et al. Central nervous system involvement in Sjögren's syndrome: unusual, but not unremarkable clinical, serological characteristics and outcomes in a large cohort of Italian patients. Rheumatology. 2010;49:1540-9.

11. Owada K, Uchihara T, Ishida K, Mizusawa H, Watabiki S, Tsuchiya K. Motor weakness and cerebellar ataxia in Sjögren syndrome-identification of antineuronal antibody: a case report. J Neurol Sci. 2002;197:79-84.

12. Manto MU, Rondeaux P, Jacquy J, Hildebrand JG. Subacute pancerebellar syndrome associated with systemic lupus erythematosus. Clin Neurol Neurosurg. 1996;98:157-60.

13. Shimomura T, Kuno N, Takenaka T, Maeda M, Takahashi K. Purkinje cell antibody in lupus ataxia. Lancet. 1993;342:375-6.

14. Gardner RC, Schmahmann JD. Ataxia and cerebellar atrophy — a novel manifestation of neuro-Behçet disease? Mov Disord. 2008;23:307-8.

15. Hirose M, Ikeuchi T, Hayashi S, Terajima K, Endo K, Hayashi T, et al. A possible variant of neuro-Behçet disease presenting chronic progressive ataxia without mucocutaneo-ocular symptoms. Rheumatol Int. 2006;27:61-5.

16. Tagliati M, Simpsom D, Morgello S, Clifford D, Schwartz RL, Berger JR. Cerebellar degeneration associated with human immunodeficiency virus infection. Neurology. 1998;50:244-51.

17. Attwood W, Poser CM. Neurologic complications of Sjögren's syndrome. Neurology. 1961;11:1034-41.

18. Terao Y, Sakai K, Kato S, Tanabe H, Ishida K, Tsukamoto T. Antineuronal antibody in Sjögren's syndrome masquerading as paraneoplastic cerebellar degeneration. Lancet. 1994;343:790,

19. Heidary M, Alesaeidi S, Afshari K. Cerebellar degeneration in primary Sjögren syndrome. BMJ Case Rep. 2018. https://doi.org/10.1136/ bcr-2017-223952

20. Kim MJ, Lee MC, Lee JH, Chung SJ. Cerebellar degeneration associated with Sjögren's syndrome. J Clin Neurol. 2012;8:155-9.

21. Farhat E, Zouari M, Abdelaziz IB, Drissi C, Beyrouti R, Hammouda MB, et al. Progressive cerebellar degeneration revealing Primary Sjögren Syndrome: a case report. Cerebellum Ataxias. 2016;3:18.

22. Maciel R, Camargos S, Cardoso F. Subacute cerebellar degeneration as the first manifestation of Sjögren's syndrome. Mov Disord Clin Pract. 2017:4:637-8.

23. Alexander EL, Lijewski JE, Jerdan MS, Alexander GE. Evidence of an immunopathogenic basis for central nervous system disease in primary Sjögren's syndrome. Arthritis Rheum. 1986;29:1223-31.

24. Zintzaras E, Voulgarelis M, Moutsopoulos HM. The risk of lymphoma development in autoimmune diseases: a meta-analysis. Arch Intern Med. 2005;165:2337-44.

25. Nocturne G, Mariette X. Sjögren syndrome-associated lymphomas: an update on pathogenesis and management. Br J Haematol. 2015;168:317-27.

\section{Publisher's Note}

Springer Nature remains neutral with regard to jurisdictional claims in published maps and institutional affiliations. 